\title{
Failure to Obtain Sample
}

National Cancer Institute

\section{Source}

National Cancer Institute. Failure to Obtain Sample. NCI Thesaurus. Code C63172.

The device does not collect or transfer the sample as intended. 